\title{
Miten kuvailla vihaa? Viron ja suomen idiomien vertailu kognitiivisen kielitieteen näkökulmasta
}

\author{
ENE VAINIK ${ }^{1}$, \\ PIRKKO MUIKKU-WERNER², \\ GEDA PAULSEN ${ }^{1,3}$ \\ Viron kielen instituutti', Itä-Suomen yliopisto ${ }^{2}$, \\ Uppsalan yliopisto ${ }^{3}$
}

Tiivistelmä. Tässä artikkelissa vertailemme vihan emootiota välittäviä viron- ja suomenkielisiä kuvaannollisia ilmauksia. Selitämme niiden erikoislaatua idiomien merkityspiirteillä ja analysoimme ilmauksia metaforateorian viitekehystä käyttäen. Sekä suomen että viron vihaidiomien kielikuvat perustuvat laajalti ruumiilliseen metonymiaan; lisäksi näissä kielissä on käytössä kansainvälisesti levinneitä käsitemetaforia kuten VIHA ON KUUMA NESTE ASTIASSA, VIHAN INTENSIIVISYys ON KUUMUUTTA, ViHA ON TULTA. Molemmissa kielissä ilmenee vihatilanteen käsitteistämisen vaiheittaisuus (vihan synty, sen vaikutus kokijaan, pyrkimys kontrolloida vihaa, kontrollin menetys, vihainen käyttäytyminen). Suomen kielessä vihaa käsitteistetään aivoihin ja päähän liittyvän toiminnan kautta, kun taas virossa kokija kuvaillaan astiana ja viha nesteenä. Molemmissa kielissä esiintyy hyperbolista kuvaannollisuutta. Virossa vihaista ihmistä karrikoidaan eläinten ruumiinosiin viittaamalla, suomessa korostuu autoaggressiivinen käyttäytymismalli.

Avainsanat: viha; idiomi; kognitiivinen metaforateoria; metonymia; metafora; vihaskenaario 


\section{Johdanto}

Ihmisen mielentila on hyvin kokonaisvaltainen asia, olivatpa kyseessä kielteiset tai myönteiset tunteet. Perustunteina voidaan pitää esimerkiksi seuraavia: ilo, suru, inho, pelko, hämmästys ja viha. Niitä ilmaistaan ja tulkitaan yleensä melko samantapaisesti jopa eri kulttuureissa. (Nummenmaa 2010: 85.) Viha on näin ollen yksi perusluonteisimpia inhimillisiä tunteita, jonka on todettu ilmenevän eri kulttuureissa ja eri aikakausilla (Chon 2002). Melkein jokaisesta maailman kielestä löytyy sana, joka tarkoittaa vihaa (Mesquita ym.1997). Viro ja suomi eivät ole siinä suhteessa poikkeuksia: käytämme jopa yhteistä sanaa viha, jonka juuret palautuvat esihistorialliseen aikaan (Vainik 2014). Viha on sekä virolaisille että suomalaisille nykypäivänäkin ajankohtainen sana. Kun koehenkilöiden piti luetella tunteiden nimityksiä siinä järjestyksessä kun ne tulevat mieleen, sekä virolaiset että suomalaiset mainitsivat juuri sanan viha yhtenä ensimmäisistä sanoista (Vainik 2002; Tuovila 2005).

Tämän artikkelin teemana oleva vihaisuus on hyvin eriasteista: henkilö voi olla silmittömän raivoissaan tai vain lievästi ärtynyt. Viha paljastuu sekä verbaalisessa että nonverbaalisessa kommunikaatiossa. Ihminen voi heitellä tavaroita, pahimmassa tapauksessa jopa käydä käsiksi toiseen. Eri muodoissaan suuttuminen näkyy vaikkapa ilmeistä (suu raottuu ja hampaat tulevat näkyville) tai silmistä (ne kapenevat ja pupillit supistuvat). Väri kasvojen tai kaulan iholla voi vaihdella, kulmakarvat kurtistuvat tai sieraimet laajentuvat. Sarjakuviin on puolestaan vakiintunut tiettyjä kiukustumisen visuaalisia symboleita. Hahmon päästä nouseva musta savu kuvaa suuttumusta; "tappava" katse on ilmaistavissa sen linjalla lentävillä veitsillä (Hänninen \& Kemppinen 1994: 86-87). Tällaisten vertauskuvien tunnistaminen on yleensä vaiva-

tonta. Jos nonverbaalinen viestintä ei edellytä "kielitaitoa", vastaavatko tunteiden erikieliset verbaaliset kuvaukset toisiaan?

Kirjallisuudessa erotetaan kaksi emootioiden kielellisen ilmaisun peruskeinoa: emotionaalinen puhe, jolloin emootiot paljastetaan vaikkapa kiroilemalla, ja emootiopuhe, jolloin tunteista kerrotaan 
eksplisiittisesti (yhteenveto eri tutkijoiden tämäntyyppisestä jaottelusta ks. esim. Bednarek 2008: 10). Tässä artikkelissa käsittelemme emootiopuhe-tyyppiin luokitettavissa olevia ilmauksia, jotka joko nimeävät tai kuvailevat vihaemootiota sekä sen kokemista. Deskriptiivisiä emootioilmauksia on kahdenlaisia: kirjaimellisia ja kuvaannollisia (Kövecses 2000: 6). Kirjaimellisia vihailmauksia ovat tietyn tunteen ja sen eri vivahteiden nimitykset (substantiivit, kuten virossa viha, nördimus, raev ja suomessa vastaavasti viha, närkästys, raivo), mutta myös tunneverbit (viron vihastama, pahandama, solvuma ja suomen vihastua, närkästyttää, loukkaantua). Tunneilmauksina esiintyvät myös adjektiivit (esim. viron vihane, suomen vihainen) ja adverbit (viron vihaselt, tigedalt; suomen vihaisesti, kiukkuisesti jne.).

Suomen kielessä on erityisen runsaasti verbijohdoksia ja verbikonstruktioita, joita käytetään emootiopuheessa ${ }^{1}$. Tunnetilaa ilmaisee suomessa tunnekausatiivilause; verbit muodostetaan enimmäkseen käyttäen kausatiivijohtimia kuten - $t t A-,-U t t A$ - tai - $t U t t A$ - (VISK $\$ 316$ ). Kokijaobjektilliset verbit ilmaisevat ärsykkeen vaikutusta kokijaan. Lause esittää kokijan jonkin, usein spesifioimattoman ärsykkeen vaikutuksen alaisena. Kokijaa edustaa partitiiviobjekti tai nolla, ärsyke voi olla subjektina. (VISK $\$ 467$.) Eri-ikäisten ärtymystä osoittavien verbien kirjo on sanakirjoissa varsin laaja: (minua) harmittaa, hatuttaa, hermostuttaa, hernettää hernetyttää, kenkuttaa, keljuttaa, kismittää, kiukuttaa, kututtaa, närkästyttää, potuttaa, raivostuttaa, sapettaa, suututtaa, vituttaa, ärsyttää. Nominatiivisubjektiakin voi käyttää tunteen kokijan ilmaisuun, mutta tällöin mielentila on ikään kuin kehkeytymässä: (kohta minä) raivostun, kiivastun, pimahdan. Toki myös adjektiivin tai adverbin varassa voidaan edetä: olen vihainen, raivoissani, äreissäni.

Viron kielessä on tunteiden ilmaisemiseen käytössä normaalilauseesta eroava lausetyyppi - kokijalause - jossa semanttinen subjekti (viroksi tegevussubjekt) eli tässä tapauksessa kokija ei esiinny lauseessa subjektina vaan lauseenalkuisena adverbiaalina (Mulle meeldib tantsida

$1 \quad$ Esimerkiksi inkoatiiviverbejä käsittelee tunteiden ilmaisemisen näkökulmasta Murmann (2019). 
'minä tykkään ("minulle miellyttää") tanssia, Tal hakkas hirm 'häntä alkoi pelottaa ("hänellä alkoi pelko")') tai objektina (Ta otsitud vabandused vihastasid mind 'hänen teennäiset anteeksipyyntönsä suututtivat minua') (Erelt 2017: 85). Virolle ominaisesti samaa tunneverbiä voi käyttää sekä transitiivisena (See jutt vihastas mind 'se juttu suututti minua') että intransitiivisena (Ma vihastasin põhjalikult 'minä suutuin ("suututin”) perusteellisesti'). Tätä ilmiötä on nimitetty verbien labiiliudeksi (Kehayov \& Vihman 2014).

Arvottavan tai tunnepitoisen asennoitumisen ilmaisemisen mahdollistavat myös idiomit (Nunberg ym. 1994: 492-493). Moonin (1998: 264-266) mielestä idiomit soveltuvat melko hyvin negatiiviseen arviointiin tai kielteisten tunteiden paljastamiseen, sillä niitä voidaan joskus pitää kohteliaampina kuin suoria keinoja. Idiomeihin saattaa sisältyä myös huumoria, joka voi toimia kevennyksenä. Lisäksi kuvallinen ilmaus on usein epäodotuksenmukaisuutensa vuoksi kiinnostava: varsinkin kirjoitetussa kielessä vähemmän ennustettava valinta on parempi kuin ennalta arvattava (kiinnostavuusperiaatteesta ks. Leech 1974: 146-147).

Tässä artikkelissa on tarkoitus keskittyä nimenomaan kuvallisiin ilmauksiin, idiomeihin, jotka paljastavat vihastumisen: sm. vetää herneet nenään ja viro süda läheb täis 'sydän tulee täyteen'. Perusoletuksemme on, että universaalisti jaetut ärsyyntymisen kokemukset ovat ilmaistavissa useilla eri tavoilla, mutta sukukielistä voisi löytää toisiaan muistuttavia sanontoja.

Suomalaisten ja virolaisten yleinen käsitys vihasta on aika samantapainen. Realo ym. (2013) ovat tutkineet virolaisten ja suomalaisten mielikuvia, joita sanan viha kirjaimelliset merkitykset luovat. Heidän tuloksensa osoittavat, että molemmissa kielissä vihan vaikutuksena kokijaan nähdään kuumuus, verenpaineen nousu, paineen tunne, lihasjännitys, kasvojen punoitus, äänen korotus, negatiivinen arvio tilanteesta. Eroja löytyi käyttäytymistendensseistä: virolaiset arvioivat, että vihaisina he jäisivät passiivisiksi tai jopa pakenisivat, kun taas suomalaiset uskoivat, että he ilmaisisivat vihaa liikkumisen kautta. Jos tällainen 
ero on todella olemassa, olisi mielenkiintoista nähdä, löytyykö sille vahvistusta idiomeista.

Olemme keränneet joukon suomalaisia ja virolaisia idiomeja ${ }^{2}$, jotka kuvaavat joko suuttumista prosessina tai suuttuneisuutta olotilana. Esimerkit ovat peräisin lähinnä sanakirjoista. Viron osalta lähteinä toimivat "Fraseoloogiasõnaraamat" (Õim 2000), sananparsien kokoelma "Eesti kõnekäänud" (Õim 2020), "Eesti keele ühendsõnastik"” sekä kuvallisen kielen tutkimukset (Vainik 2016). ${ }^{4}$ Suomen kielen aineisto on poimittu Muikku-Wernerin, Jantusen ja Kokon fraasisanakirjasta "Suurella sydämellä ihan sikana" ja Marja Nenosen väitöskirjan "Idiomit ja leksikko" sanalistoista. Emme etsi kontrastiivisesti kahden kielen idiomien välisiä suoria vastaavuuksia vaan laajemmin vastauksia seuraaviin kysymyksiin:

1) Millaisilla idiomeilla virossa ja suomessa ilmaistaan vihastumiseen kytkeytyviä tunteita?

2) Onko sukukielten väliltä löydettävissä yhtäläisyyksiä ja eroja, ja miten niitä voisi kognitiivisen metaforateorian avulla selittää.

Teoreettiset lähtökohtamme on esitelty luvussa 2. Luvussa 3 on kuvailtu idiomeissa käytettyä keskeistä sanastoa ja sen taustoja. Luvussa 4 valittuja idiomeja analysoidaan tukeutuen käsitemetaforateoriaan. Saatuja tuloksia ja niiden merkitystä pohdiskelemme luvussa 5 .

\section{Teoreettinen tausta}

Tutkimuksen teoreettisen viitekehyksen muodostavat erilaiset näkökulmat, joiden kautta voidaan lähestyä idiomien olemusta, niiden metaforisuutta ja käsitteellistä hahmottelua sekä käsitteistä motivoituja

\footnotetext{
2 Viron aineistossa oli noin 70 ilmaisua, suomen aineistossa noin 110. Koska ilmausten laskemista vaikeuttaa niiden variointi, tarkkaa lukua on vaikea määritellä. Tässä artikkelissa esitämme kuvaavia esimerkkejä, emme aineistoa kokonaisuutena. 3 "Eesti keele ühendsõnastik" (viron kielen yhdistetty sanakirja) kokoaa monien elektronisten sanakirjojen tietoa ja on käytettävissä internetissä: https://sonaveeb.ee/ (13.1.2021).

$4 \quad$ http://www.eki.ee/dict/efi/ (28.1.2021). 
konstruktioita. Idiomi on Langackerin (1987: 25) mukaan määriteltävissä sellaisten semanttisten ja symbolisten suhteiden kokonaisuudeksi, joka on konventionaalistunut ja yhdistynyt vakiintuneeksi rakenteeksi. Moon (1998: 3) puolestaan pitää idiomia yhtenä kiinteiden ilmausten alalajina, tietynlaisena vakiintuneena yksikkönä, fraasilekseeminä. Jonkinasteisina, joskus jopa vastakohtaistuvina sukulaiskategorioina mainitaan formulat, kiinteät fraasit, sanomukset, sananlaskut ja alluusiot (Nunberg ym. 1994: 492). Esimerkiksi sanalaskuista idiomit erottuvat sen vuoksi, etteivät ne tavallisesti yksinään muodosta itsenäistä lausetta (Nenonen 2002: 8). Asta Õim määrittelee idiomin yhtenä idiomaattisten ilmausten (sanaliittojen) lajina, jota luonnehtii kolme tekijää: semanttinen modifiointi, opaakkius ja denotaatioon viittaamisen monimutkaisuus (Õim 2019: 19). Tiina Onikki-Rantajäskön (2001: 184) mukaan idiomikonstruktion laajuus voi vaihdella yksittäisestä morfeemista jopa useiden lauseiden muodostamaan syntaktiseen kokonaisuuteen asti. Idiomeissa on tutkijoita kiinnostanut yhtäältä niiden suhde sanastoon ja syntaksiin, toisaalta niiden funktio. Sanakirjoja niistä on tehty säännöllisin väliajoin. (Moon 1998: 12-18; koostettu näkemys ks. myös Nenonen 2002: 6-7; määritelmistä ks. Häkkinen 2000; Mäntylä 2004.)

Idiomin olemusta luonnehtivan onkin otettava huomioon monia piirteitä. Niistä tärkeimpiä ovat Nunbergin, Sagin ja Wasowin (1994) mielestä muun muassa seuraavat ominaisuudet. Idiomit ovat konventionaalisia kokonaisuuksia, eikä niiden merkitys synny pelkästään osien merkitysten summana. Idiomit esiintyvät melko harvoissa konstruktioissa. Usein ne rakentuvat kielikuvien varaan, mutta toisaalta ne voivat viihtyä epämuodollisissa, puhekieltä suosivissa tilanteissa. Tyypillistä on niihin kytkeytyvä arvottava tai affektinen asennoituminen. (Mts. 492-493.)

Keskitymme lähinnä idiomien metaforisuuden lähtökohtiin. Useimmiten niihin törmäävä joko tietää tai osaa tulkita niiden merkityksen. Apuna on ikään kuin uudelleen luotu samankaltaisuus, jonka varassa on alun perin siirrytty kirjaimellisesta merkityksestä laajennettuun kuvalliseen merkitykseen (Langlotz 2006: 114). On ajateltu, että idiomien 
tulkintaa helpottaa kirjaimellisen ja kuvallisen merkityksen samanaikainen aktivoituminen. Toisaalta on todettu, ettei kaikilla idiomeilla edes ole kirjaimellista merkitystä (esim. suomen soittaa poskeaan) (Flores d'Arcais 1993: 80) tai kyseisessä tilanteessa se ei lainkaan tule mieleen (Gehweiler ym. 2007: 109). Periaatteessahan oletetaan, että kuvallinen tulkinta syrjäyttää kirjaimellisen, joten pelkästään figuratiivisuudenkin perusteella voidaan jäljittää idiomin merkitys (Kövecses 2002: vii). Idiomien merkitys ei silti yleensä ole täysin satunnainen vaan (kognitiivisesti) motivoitunut, ikään kuin semanttisesti läpinäkyvä (Kövecses 2002: 202).

Erilaisia muun muassa tunteisiin viittaavia kielikuvia voidaan lähestyä nojautuen Lakoffin ja Johnsonin (1980) kognitiiviseen metaforateoriaan, jonka mukaan metafora ei ole pelkästään kielen ilmiö vaan oleellinen osa ihmiskognitiota. Idiomeja ymmärretään, koska niitä motivoi metaforinen konseptuaalinen tieto, erilaiset käsitemetaforat (Gibbs 1993: 67). Tulkinnoissa kytketään toisiinsa kahden eri käsitetason ja käsitteistön ilmiöitä, jolloin yhden tason ilmiö on ymmärrettävissä toisen tason ilmiön avulla. Se, millainen potentiaali idiomilla on tuoda mieleen kuvallisuutta, riippuu Langlotzin (2006: 51) mukaan käsitteen konkreettisuudesta. Metaforisessa ilmauksessa samaistetaan kaksi toisiinsa liittymätöntä sanaa, ja metonyymisessä ilmauksessa yhteen käsitteeseen viitataan nimeämällä jokin toinen, siihen läheisesti liittyvä käsite. Molemmissa tapauksissa ymmärtämisen avuksi otetaan toinen alue, jota kutsutaan lähdealueeksi (esim. MATKA, SOTA, RAKENNUS, KASVI yms.). Ymmärretyksi tuleva alue on kohdealue (esim. RAKKAUS, IDEAT, ARGUMENTIT yms.). Käsitemetaforista tunnetuimpia on ELÄMÄ ON MATKA, jonka varaan rakentuu vaikkapa sellaisten lauseiden merkitys kuin Älä tule tielleni! tai Oli pakko välillä vähentää vauhtia. (Lakoff \& Turner 1989: 203; Leech \& Short 1986: 151; Kövecses 2002: 4.)

Kognitiivista metaforateoriaa on sovellettu tunteiden kuvaannollisen kielen analyysissa. Lakoffin ja Kövecsesin (1987) tutkimus amerikanenglannin käsitteistämästä vihan kognitiivisesta kansanmallista (tai 
kulttuurisesta mallista, eng. folk model) on ollut tässä uraauurtava. Samankaltaista lähestymistä on sovellettu tuloksekkaasti tutkittaessa esimerkiksi unkarin (Bokor 1997), japanin (Matsuki 1995), zulun (Tailor \& Mbense 1998), kiinan (Yu 1995), arabian (Maalej 2004) ja viron (Vainik \& Velt 2006) vihailmauksia. Näissä tutkimuksissa on analysoitu kuvallisia ilmauksia siitä kannalta, millaisia käsitteellisiä metaforia niissä ilmenee (esim. VIHA ON KUUMA NESTE ASTIASSA, VIHA ON TULTA, VIHA ON VIHOLLINEN), mutta myös vihan emootiosta yleisemmän naiiviteoreettisen ${ }^{5}$ käsityksen näkökulmasta (ns. kognitiivinen malli). On nimittäin arvioitu, että vihaa kuvataan monivaiheisena tapahtumana, jonka keskeisenä tekijänä on vihan kokija. Vihatapahtuma koostuu viidestä vaiheesta, joita käsittelemme yksityiskohtaisesti luvussa 4.3.

Viron ja suomen vihaidiomien vertailussa on kiinnostavaa, toimivatko kuvallisten ilmausten lähtökohtina samankaltaiset aihepiirit ja esiintyykö eroja ilmausten jakaantumisessa vihan kansanmallin vaiheisiin.

\section{Katsaus vihan idiomeihin}

Idiomien tarkastelussa huomio voidaan kiinnittää esimerkiksi vihan puhkeamiseen tai siihen, millainen vaikutus sillä on kokijaan. Suuttunut voi ikään kuin revetä nahoistaan (viroksi endast välja minna 'tulla hyvin vihaiseksi', kirjaimellisesti "mennä ulos itsestänsä"). Toisaalta voi sanoa että hänellä on hambad ristis 'hän yrittää pidättää vihansa' ("hampaat ristissä”). Kulloinenkin ilmaus kuvaa erilaista suuttumusta, ja kokemuksen intensiteetti vaihtelee: Suomessa jotakuta ottaa kupoliin, joltakulta menee hermot, tai hän repii pelihousunsa. Virossa joku läheb närvi 'alkaa tulla hieman vihaiseksi' ("menee hermoon”) ja jonkun silmad pilluvad

5 Ns. naiiviteorioita luonnehtii niiden kulttuurinen tai kollektiivinen alkuperä. Niillä ymmärretään kulttuurikontekstissa omaksuttavia kognitiivisia rakenteita vastakohtana yksilölliseen käsitteistämiseen (ks. esim. Asta Õim 2003). Viron kielentutkimuksessa alun perin antropologiasta peräisin olevan naiiviteorian käsitteen otti käyttöön Haldur Õim $(1999,2008)$. 
tuld 'joku heittelee vihaisia katseita' ("silmät heittelevät tulta"). Toisaalta voidaan tarkastella sitä, mitä ärsyyntymisen ulkoisia merkkejä idiomissa mainitaan: suomessa esimerkiksi Villeltä nousee savu päästä ja virossa Ville tõmbub turri 'Ville vetäytyy pörhölleen'.

Idiomeissa käytetty sanasto on usein yllättävää, mutta tavalla tai toisella kielelliset valinnat saavat selityksensä fraasien luomasta todellisuudesta. Heränneet tuntemukset ovat epämieluisia, joten vihan kokija käy kuumana tai saa hepulin ja reagoi poikkeuksellisesti: hän räjäyttää hattunsa tai saa näppylöitä. Käytetyt verbit ovat yleensä vahvasti toiminnallisia: vetää herneet/porot/rypsit nenään, pinna palaa, polttaa hihansal päreet, räjähtää tai repiä pelihousunsa/paitansa/rotsinsa/hameensa (ks. esim. Nenonen 2002: 155, 175). Fraasien ymmärrettävyyttä lisää se, että ne ovat vahvan visuaalisuutensa vuoksi läpinäkyviä: polttaa proput tai rusikat näitama 'näyttää nyrkkiä. Jos jollakulla kupit menevät nurin, hän ei ole kovin hyväntuulinen. Viron karvu turri ajama 'tulla vihaiseksi' ("pörhistää karvat") tuo mieleen karvansa nostavan vihaisen koiran.

Joskus idiomiin liittyy toisiin kulttuureihin viittaava konteksti, kuten härkätaistelu: matadorin punainen muleta saa härän raivostumaan. Tähän tapahtumaan perustuva idiomi löytyy monista kielistä: esimerkiksi saksan rot sehen, englannin to see red, suomen nähdä punaista. Virossa tätä mielikuvaa käytetään vihaa aiheuttavasta ilmiöstä vertailun muodossa: justkui punane rätt härjale (vrt. suomi kuin punainen vaate). Aina lainautumista ei pystytä todistamaan, mutta idiomienkin on todettu siirtyvän kielestä toiseen: englannin ilmausta blow a fuse vastaa suomen polttaa proppunsa/sulakkeensa; saksan verbin explodieren korvaa suomen räjähtää ja viron (vihast) plahvatama. (Muikku-Werner 2017: 59-63.)

Suomalaisissa tunnetiloja kuvaavissa idiomeissa on usein ottaaverbi. Tällöin sen vakiintuneimmat merkitykset, kuten 'siirtää jotakin jostakin pois' tai 'saattaa jotain haltuunsa', jäävät syrjään. Kokonaisuus on myös syntaktisesti melko jähmeä: KOKIJA $+\mathrm{V}+\mathrm{N}_{\text {illativi//lativi/allativivi }}$ mikä johtuu osittain siitä, ettei näissä lauseissa yleensä ole subjektia. Verbiin liittyvän paikallissijan valinnalla voi korostaa jatkuvakestoisuutta 
(illatiivi: ottaa päähän) tai äkillisyyttä (elatiivi: ottaa päästä). (Nenonen 2002: 79, 105-106.) Virolaisissa idiomeissa suositaan muun muassa verbiä ajama: marru ajama 'tehdä joku hyvin vihaiseksi' ("ajaa myrskyyn”), harja punaseks/lillaks ajama 'tehdä joku hyvin vihaiseksi' ("ajaa (jonkun) harja punaiseksi/violetiksi”) tai okkaid välja/püsti/turri ajama 'tulla hieman töykeäksi' ("ajaa piikit ulos/pystyyn/törölleen”).

Neutraalimerkityksiset verbit olla ja saada voivat yhdistää käsitteitä toisiinsa: (kellelgi) hing/elu on täis tai hing saab täis 'joku on hyvin vihainen' (“(jonkun) henki/sielu/elämä on täysi / tulee täyteen”). Joskus raivostumisen samankaltaisuus jonkin luonnonilmiön tai eläimen kanssa ilmaistaan eksplisiittisen vertailun (nagu/kuin) kautta: nagu äikesepilv olema 'olla kuin ukkospilvi' tai nagu siil turris olema 'olla piikit pörhöllään kuin siili'. Suomessa joku voi olla kiukkuinen kuin ampiainen, äkäinen kuin perseeseen ammuttu karhu tai kireä kuin viulunkieli.

\section{Analyysi}

Seuraavassa tarkastelemme, millaisiin metonyymisiin ja metaforisiin siirtoihin suomen ja viron vihaidiomit perustuvat. Haluamme selvittää, miten läheisiä suomen ja viron vihakokemuksen käsitteistykset ovat toisilleen.

\subsection{Metonymialla motivoituja idiomeja}

Emootiot ovat monitahoisia ja kompleksisia. Niihin sisältyy sekä leimallisia ilmeitä, tilanteen kognitiivista arviointia sekä muutoksia kehon asennossa ja käyttäytymistä ohjaavissa kuvioissa (esim. hyökkää tai pakene). Emootioiden vaikutus näkyy myös fysiologiassa (esim. hengityksen tiheyden ja syvyyden muutoksissa, sydämen rytmissä, verenkierrossa jne.). Eräs yleinen tapa ilmaista vihaa on korostaa kehon reaktioita: ne ikään kuin edustavat kokonaisuutta, tunnetta (pars pro toto). Kognitiivisen metaforateorian termein tilanteen voi yleisesti ilmaista näin: кEHON OIRE EDUSTAa TUNNETTA (Vainik 2016: 19-22). 
Erilaiset ruumiinosat ovatkin osallisina monissa idiomikonteksteissa (suomen kielen suosituimmista nomineista ks. Nenonen 2002: 112-117). Myös viha on kuvattavissa fyysisten oireiden avulla. Sisäelimistä virossa mainitaan keuhko ja maksa: kops läheb üle maksa '(joku) tulee hyvin vihaiseksi' ("keuhko menee maksan yli"). Slangi-ilmauksena tunnetaan (kellelegi) põiele / põie peale käima 'hermostuttaa' ("käydä rakolle"). Ruumiillinen oire, jota tämäntapaiset ilmaukset välittävät, on voimakkaaseen vihaan liittyvä kokijan sisäinen paine: PAINEEN TUNNE EDUSTAA VIHAN INTENSIIVISYYTTÄ.

Erityisen suosittuja "tuntevia elimiä" ovat virossa veri, sappi ja sydän. Sappinesteen kitkeryys sopii hyvin vertailukohteeksi (sAPEN KITKERYYS EDUSTAA VIHAN EPÄMIELLYTtÄVyYtTÄ, ks. Vainik 2018): sappi kallama / välja valama 'puhua vihaisesti' ("kaataa/vuodattaa sappea"), süda sappi täis 'joku on hyvin vihainen, täynnä tukahtunutta vihaa' ("sydän täynnä sappea"). Suomessakin sappi on täysi, se kiehuu/kiehahtaa/kuohuu tai jotakuta sapettaa. Viittaus sappeen vihan kokemuksen välittäjänä ei selvästikään kuvaile pelkästään metonyymistä suhdetta, vaan se on jäänne ns. ruumiinnesteteoriasta. Tämä on antiikista alkunsa saanut ja vielä uuden ajan lääketieteessäkin tunnettu käsitys neljän ruumiinnesteen - veren, mustan sapen, keltaisen sapen sekä liman - tasapainosta tai tasapainottomuudesta ihmiselimistössä. Juuri tämän teorian perusteella ihmiset on jaettu neljään temperamenttityyppiin ja ruvettu puhumaan koleerisesta, sangviinisesta, flegmaattisesta tai melankolisesta temperamentista (ks. Geeraerts \& Grondelaers 1995).

Sydän on kautta aikojen hahmotettu niin hyvien kuin pahojen tunteiden tyyssijaksi, joka kuvitellaan ihan kuin ASTIAKsı. Tällöin metonyymiseen viittaukseen (sYDÄN EDUSTAA TUNTEITA) yhdistyy myös metaforinen siirto. Viro: tal on süda täis 'hän on vähän vihainen' ("hänellä on sydän täysi/täynnä"), südant täis ajama 'tehdä vihaiseksi' ("ajaa (jonkun) sydän täydeksi”) tai süda läheb/saab täis 'suuttua/tulla vihaiseksi' (“(jonkun) sydän tulee täydeksi”). Samanlaista mallia noudattaa idiomi süda kasvab '(joku) tulee vielä vihaisemmaksi' ("sydän kasvaa”). Liioitteleva etelävirolainen ilmaus süäme ots suust väläh ('sydämen kärki suusta 
ulkona') havainnollistaa verbaalista tunteenpurkausta. Tässä fraasissa vihan voimistumisen kuvausta tehostetaan esittelemällä mahdoton, järjenvastainen tapahtuma. Ilmaus süda täis kui seatapjal 'hyvin vihainen' ("sydän täysi kuin siantappajalla") perustuu vertailuun. Suomessa on raivostumista ilmaiseva verbi sydämistyä.

Hermojen liittyminen vihastumiseen on fysiologinen tosiasia. Mieltämme rauhoittaa vagus- eli kiertäjähermo, joka on tietynlainen ihmiskehon jarrutusjärjestelmä. Sen toiminnan heikentyminen aiheuttaa ylimitoitetun reaktion. Hermot ovat mukana monissa idiomeissa: närv läheb mustaks 'ärsyyntyä' ("hermo menee mustaksi"; vrt. suomen mieli mustenee), läheb närvi ärsyyntyä' ("menee hermoon"). Vihan aiheuttamista jollekulle muulle kuvaavat (kellelegi) närvidele käima 'käydä (jonkun) hermoille', närvi/närve mustaks/krussi ajama ärsyttää, hermostuttaa' ("ajaa (jonkun) hermot mustaksi/sykkyrälle"), närvi ajama ärsyttää ("ajaa hermoon"). Niissä metonymia voi olla HERMOT EDUSTAVAT NEGATIIVISTA MIELIALAA.

Suomessa viron tavoin voi vaikkapa epäonnistuminen ottaa hermoon tai käydä hermoille. Hermot voivat olla riekaleina, hermo (myös arkinen metafora pinna) on kireällä tai katkeaa. Jopa lainasana on käytössä: nervit menee kireälle (Nenonen 2002: 151). Hermot myös pettävät, tai lyhyesti nyt meni hermot. Näissä tapauksissa metonymia on HERMOT EDUSTAVAT KONTROLLIKYKYÄ.

Ajatusten ja ehkä reagoinninkin kontrollin voi kuvitella olevan yhteydessä aivojen toimintaan. Silloin miellyttävän tilanteen häiriytyminen ottaa aivoon tai aivosta.

Myös verenpaine on mielialan mittari. Liian korkeaksi sen saattaa kohottaa stressi. Kun jokin asia nostaa verenpainetta tai verenpaine nousee, asianomainen tulee kiukkuiseksi. Lisäksi suuttumus on usein nähtävissä kasvojen tai kaulan ihon punertumisesta: (kellelgi) lööb veri pähe '(joku) tulee vihaiseksi' ("veri lyö päähän”), (kellelgi) verd pähe ajama 'tehdä (joku) vihaiseksi' ("ajaa verta päähän”), (kellelgi) sarvi verele ajama 'tehdä (joku) hyvin vihaiseksi' ("ajaa (jonkun) sarvet verille”). Suomessakin veri nousee päähän. Lisäksi suomen kielessä vihan emootion välittää 
hengityksen vaikeutumista kuvaava ilmaus vetää herneet/porot/rypsit nenään, joka nojaa metonyymiseen malliin NENÄ EDUSTAA HENGITYSTÄ JA HENGITYKSEN ESTYMINEN EDUSTAA VIHAA.

Myös kehon ulkoiset osat ovat mukana sanonnoissa (Vainik 2011). Kiukustunut voidaan kasvojensa punaisen värin takia rinnastaa kukkoon, jonka hari 'harja, heltta' voi olla punane 'punainen' tai hari punetab 'harja punertaa'. Tätä motivoi metonymia PUNAINEN KASVONVÄRI EDUSTAA VIHAA. Joskus kirjaimellisen merkityksen kuvaama ilmiö tai tapahtuma on jossain määrin poikkeuksellinen. Tällöin liioittelevilla ilmauksilla kuvataan tapahtumia, jotka eivät kirjaimellisesti ymmärrettynä ole mahdollisia (Wierzbicka 1999). Esimerkiksi virossa kokija saattaa olla vihast sinine/ roheline 'vihasta sininen/vihreä. Viha ei näyttäydy pelkästään kasvojen punaisuutena, vaan mukaan tulee muita, epätodennäköisiä värejä. Suomen kielessä kasvoissa tapahtuvia muutoksia välittää ilmaus (joku) saa näppylöitä.

Virossa vihastumisesta kertovat hampaisiin liittyvät idiomit: hambaid näitama 'osoittaa vihamielisyyttä' ("näyttää hampaitaan"), hambaid kiristama 'tukahduttaa vihansa' ("kiristellä hampaitaan"), hambad ristis 'voimakkaasti ponnistellen, tunnekuohua tukahduttaen' ("hampaat ristissä”). Suomessa vastaava ilmaus on hampaat irvessä, mutta ärtynyt suomalainenkin saattaa kiristellä hampaitaan.

Vihastumisesta kertoo nyrkissä oleva käsi: viroksi käsi on rusikas "käsi on nyrkissä" tai näitama rusikat ("näyttää nyrkkiä"), suomen heristää nyrkkiä. Suomen fraasit nyrkit ojossa tai tanassa eivät ole varsinaisia idiomeja mutta kuvaavat kuitenkin suuttuneen olemusta. Saksalaisessa kielitieteessä käsitellään tämäntapaisia eleihin viittaavia ilmauksia kuitenkin eräänä idiomityyppinä, jota kutsutaan kinegrammeiksi (Dobrovol'skij \& Piirainen 2005: 99). Näitä idiomeja luonnehtii tulkinnan kaksitasoisuus: toisaalta suora viittaus eleeseen, toisaalta viittaus eleen konventionaaliseen merkitykseen. Nyrkkiin puristettu käsi viestii mahdollisesta aggressiivisuudesta. Sekä hampaisiin että nyrkkeihin viittaavia ilmauksia motivoi metonymia TYYPILLINEN ELE EDUSTAA VIHAA. 
Myös vihainen käyttäytyminen on osa vihan kokemisen tapahtumasta. Siksi voidaan sanoa, että myös suomen ilmaukset räjäyttää hattunsa ja repiä pelihousunsa (tai paitansa/rotsinsa/hameensa) ovat luonteeltaan metonyymisiä. Näiden idiomien kirjaimellinen merkitys viittaa autoaggressiiviseen käyttäytymiseen (КÄYTTÄYTYMINEN EDUSTAA VIHAA). Luonnollisesti kyse on liioittelusta: ilmauksella luodaan epäuskottava tai jopa mahdoton tapahtuma.

Tiettyjen ruumiinasentojen ja kasvojen ilmausten on väitetty korreloivan tiettyjen emotionaalisten tai psykofyysisten tilojen kanssa (Onikki-Rantajääskö 2006: 69-70). Vihaa voi ilmaista metonyymisesti myös seuraavasti: kärss/turi on püsti 'olla vihainen' ("kärsä/niska on pystyssä”), sarvi püsti ajama 'suututtaa joku vakavasti' ("ajaa sarvet pystyyn"). Näissä tapauksissa vihamielikuvaan liittyy viitteitä (koti) eläimiin sekä siihen, että intensiivisessä tunnetilassa olevan ruumiinasento saattaa erota tavallisesta. Suomessa vastaavasti karvat/hiukset nousevat pystyyn. Näissä tapauksissa toimii metonymia VERTIKAALINEN RUUMIINOSA EDUSTAA NEGATIIVISTA EMOTIONAALISTA AKTIVAATIOTA. (Vainik 2011: 60.)

Virossa ulkoisista ruumiinosista käytetään viittauskohteena karvoja ja hiuksia: karvu turri ajama 'tehdä tai tulla vihaiseksi' ("ajaa karvat pörhölle"); karvad hammaste peal ("karvat hampailla") kuvailee vihaista puhetta, vihan verbaalista ilmaisemista. Viimeinen ilmaisu on äärimmäisen kuvallinen ja konstruoi "olemattoman tapahtuman". Suomessa joku jopa repii hiuksiaan (Nenonen 2002: 169).

Katseen merkitystä korostetaan nonverbaalisen viestinnän yhteydessä. Virossa silmad pilluvad tuld/sädemeid/välke "silmät heittelevät tulta/kipinöitä/salamoita", silmad välguvad vihast "silmät välähtelevät vihasta”. Myös suomessa silmät palavat/säkenöivät/salamoivat (Nenonen 2002: 179). Molemmissa kielissä siLMät edustavat viHAista KATSETTA.

Aiemmin mainittuja aivoja saattaa metonyymisesti edustaa myös pää. Suomen suurtaajuisimpia suuttumisidiomeja on ottaa päästä tai päähän, joiden varaan rakentuu lukuisia toisintoja. Elatiivivaihtoehdon 
katsotaan ilmaisevan lyhytkestoisempaa tilaa kuin illatiivin (Nuutinen 2012). Päähän kytkeytyvät muut seikat johtanevat seuraaviin muunnelmiin: ottaa ohimoon/takaraivoon/lettiin, jopa hilseeseen/hattuun/ pipoon. Pään muoto puolestaan on ehkä myötävaikuttanut seuraavien varianttien syntyyn: ottaa pollaan tai boltsiin (näiden taustalla on ruotsin sana boll 'pallo'), kupoliin ja nuppiin. Selittääkö vihannesten pyöreys vielä seuraavatkin idiomit: ottaa kaaliin tai lanttuun? Pannuun, koppaan (esim. piipunkoppa 'piipunpesä) tai koteloon ottamiselle onkin jo vaikeampi löytää suoraa yhteyttä ärsyyntymisen kanssa. Tällainen uusien idiomien jatkuva tuottaminen vanhoihin malleihin tukeutuen on suomessa tavallista. Ilmaistaessa vihaa virossa ei käytetä sanoja pää tai aivot. Pähe võtma tarkoittaa 'päättää vakaasti, saada päähänsä; aru pähe võtma ("ottaa järki päähän") on 'tulla järkiinsä. Virossa siis toimii metonymia PÄÄ EDUSTAA JÄRKEÄ.

Myös eläinten ruumiinosat voivat olla idiomien lähtökohtana. Virossa vihaa voi ilmaista kielikuvilla, jotka aktivoivat metonymian mukaan taustamielteen (koti)eläimestä, esimerkiksi koirasta (turris olema 'olla vihainen' (“olla pörrössä")) tai siilistä (okkaid püsti ajama 'nostaa piikit pystyyn'). Näistä ilmauksista syntyy helposti paralleeli vihaiseen ihmiseen. Kotieläimiin liittyvät lisäksi metonyymisesti käytetyt sanat kärss 'kärsä' ja hari 'harja' ilmauksissa kärss on püsti 'olla vihainen' ("kärsä on pystyssä”) sekä hari läheb punaseks 'harja tulee punaiseksi'. Sarvipäisiin eläimiin kytkeytyy puolestaan idiomi sarvi püsti/verele ajama 'nostaa sarvet pystyyn (ajaa verille)'.

Yhteenvedon metonymiaan perustuvista idiomeista esittää taulukko 1 , jossa näkyvät metonyymiset siirtomallit sekä niihin liittyvät ruumiinosat viron ja suomen kielessä. Taulukosta ilmenee, että molemmissa kielissä viitataan vihaan varsin samantapaisesti joidenkin sisäisten (veri, sydän, sappi) ja ulkoisten ruumiinosien (silmät, hampaat, nyrkki) kautta. Kuitenkin löytyy myös eroja: virossa esiintyy kokijan sisäiseen paineen tuntoon perustuvia metonymioita, joita suomessa ei ole; suomessa sitä vastoin vihan kokemus liittyy aivojen aktivaatioon, mikä puuttuu virosta. 
TAULuкко 1. Vihailmausten metonyymiset siirrot sekä niihin liittyvät ruumiinosat viron ja suomen kielessä

\begin{tabular}{|c|c|c|c|}
\hline Ruuminosa $^{*}$ & Metonymiat & Suomi & Viro \\
\hline keuhkot & $\begin{array}{l}\text { PAINEEN TUNNE EDUSTAA VIHAN } \\
\text { VOIMAKKUUTTA }\end{array}$ & & + \\
\hline maksa & $\begin{array}{l}\text { PAINEEN TUNNE EDUSTAA VIHAN } \\
\text { VOIMAKKUUTTA }\end{array}$ & & + \\
\hline rakko & $\begin{array}{l}\text { PAINEEN TUNNE EDUSTAA VIHAN } \\
\text { VOIMAKKUUTTA }\end{array}$ & & + \\
\hline veri & $\begin{array}{l}\text { VERENPAINEEN NOUSU EDUSTAA NEGATIIVISTA } \\
\text { EMOTIONAALISTA AKTIVOINTIA }\end{array}$ & + & + \\
\hline sappi & $\begin{array}{l}\text { SAPEN KITKERYYS EDUSTAA VIHAN } \\
\text { EPÄMIELLYTTÄVYYTTÄ }\end{array}$ & + & + \\
\hline sydän & SYDÄN EDUSTAA TUNTEITA & + & + \\
\hline hermot & $\begin{array}{l}\text { HERMOT EDUSTAVAT NEGATIIVISTA MIELIALAA } \\
\text { HERMOT EDUSTAVAT KONTROLLIKYKŸ̈ }\end{array}$ & + & + \\
\hline aivot & $\begin{array}{l}\text { AIVOJEN TOIMINTA EDUSTAA NEGATIIVISTA } \\
\text { EMOTIONAALISTA AKTIVOINTIA }\end{array}$ & + & - \\
\hline kasvot & PUNAINEN KASVONVÄRI EDUSTAA VIHAA & & + \\
\hline pää & $\begin{array}{l}\text { PÄÄ EDUSTAA AIVOJA } \\
\text { AIVOJEN TOIMINTA EDUSTAA NEGATIIVISTA } \\
\text { EMOTIONAALISTA AKTIVOINTIA }\end{array}$ & + & \\
\hline silmät & SILMÄT EDUSTAVAT VIHAISTA KATSETTA & + & + \\
\hline nenä & $\begin{array}{l}\text { NENÄ EDUSTAA HENGITYSTÄ } \\
\text { HENGITYKSEN ESTYMINEN EDUSTAA VIHAA }\end{array}$ & + & \\
\hline hampaat & ELE EDUSTAA VIHAA & + & + \\
\hline nyrkit & ELE EDUSTAA VIHAA & + & + \\
\hline $\begin{array}{l}\text { karvat, } \\
\text { hiukset }\end{array}$ & $\begin{array}{l}\text { VERTIKAALINEN RUUMIINOSA EDUSTAA } \\
\text { NEGATIIVISTA EMOTIONAALISTA AKTIVOINTIA }\end{array}$ & + & + \\
\hline heltta & PUNAINEN KASVONVÄRI EDUSTAA VIHAA & & + \\
\hline piikit & $\begin{array}{l}\text { VERTIKAALINEN RUUMIINOSA EDUSTAA } \\
\text { NEGATIIVISTA EMOTIONAALISTA AKTIVOINTIA }\end{array}$ & & + \\
\hline & LIIOITELTU KÄYTTÄYTYMINEN EDUSTAA VIHAA & + & \\
\hline
\end{tabular}

* Sekä sisäinen, ulkoinen että eläimen ruumiinosa; + 'esiintyy' 
Virossa huomio kohdistuu kasvojen punaiseen väriin, mikä hyperbolisesti laajentuu toisiin väreihin; suomessa huomioidaan vihaisen ihmisen tavallisesta poikkeava hengitys sekä liioiteltu käyttäytyminen. Virossa kuvataan myös (koti)eläinten ruumiinosia. Näissä käsitteistyksissä taustalla toimii metafora IHMINEN ON ELÄIN.

\subsection{Metaforilla motivoituja idiomeja}

Kuvaannolliset ilmaukset auttavat meitä ymmärtämään, miten vihan metaforinen käsitteistäminen toimii. Idiomien analyysissa on mahdollista nojautua myös kognitiiviseen metaforateoriaan. Tällöin lähtökohtana ovat erilaiset käsitemetaforat (Gibbs 1993: 67). Fraasin ymmärtämiseksi pyritään erittelemään niissä käytettyjä kuvia. Metaforisuus ilmenee siten, että yhden käsitetason ilmiö tulkitaan kytkemällä siihen toisen tason ilmiö. Kielellinen ilmaisu osoittaa nimittäin ns. lähdealueen, mikä auttaa käsitteistämään ja kuvailemaan niinkin monitasoista psykologista ilmiötä kuten viha.

On havaittu, että yleisimpiä metaforia monissa kielissä on viHA ON KUUMA NESTE ASTIASSA (Kövecses 2000: 142-146). Tämä metafora ilmenee virossa ja suomessa kiehumisilmauksissa: virossa ta kees vihast üle 'hän ei pystynyt hallitsemaan vihaansa' ("hän kiehui yli vihasta"), (kellelgi) veri keeb '(joku) on hyvin vihainen' (“(jonkun) veri kiehuu”), verd keema/kihama ajama/panema 'suututtaa, ärsyttää' ("ajaa (jonkun) veri kiehumaan"); suomessa veri kiehuu ja sappi kiehuu. Kuumaverisyys on helposti suuttuvan henkilön ominaisuus.

Joissakin ilmauksissa metaforana toimii VIHA ON PAINEEN ALLA OlEVAA AINETTA ASTiAssa. Esimerkiksi (joku) räjähtää, hän oli haljeta kiukkuunsa; virossa vastaavasti ta plahvatas vihast 'hän ei pystynyt hallitsemaan vihaansa' ("hän räjähti vihasta") ja vihast lóhki minema ("haljeta vihasta"). Tässä metaforassa tulee esiin vihan vaarallisuus: se ei suuntaudu pelkästään kokijaan vaan myös niihin, jotka sattuvat olemaan lähellä. 
Näiden kompleksisten metaforien ohella löytyy sellaisiakin, jotka kytkeytyvät erilaisiin tunteen kokemustilanteen aspekteihin. Yksi niistä keskittyy kokijaan, joka samastetaan jonkinlaiseen säiliöön tai astiaan: кOKIJA ON ASTIA. Tällaiseen mielikuvaan viittaavat esimerkiksi "täynnä olemisen" idiomit: viron tal on süda/hing täis 'hän on hyvin vihainen' ("hänellä on sydän/sielu täysi/täynnä"), südant/hinge täis ajama 'tehdä vihaiseksi' ("ajaa (jonkun) sydän/henki täydeksi”) tai süda läheb / saab täis 'tulla vihaiseksi' (“(jonkun) sydän tulee täyteen”), hing kargab/saab täis "henki hyppää/tulee täyteen', mõõt/vihakarikas sai täis 'tuli hyvin vihaiseksi ja menetti kontrollin' (“mitta/vihan malja tuli täyteen”). Suomen kielessä mitta tulee täyteen, mittani on täynnä. AstıA-metaforaan lomittuu pars pro toto -metonymia, jolloin joko sydän tai sielu, eli tunteiden ns. symbolinen sijainti, edustaa ihmistä kokonaisuutena. Metaforan ja metonymian nivoutuessa yhteen syntyy ilmiö, jota kirjallisuudessa nimitetään metaftonymiaksi (Goossens 1990). Astia ei ole ainoa tapa kuvata kokijaa, ja suomesta löytyykin ilmaisuja, joiden kokijan käsitteistys on кокІјА ON коNE, esimerkiksi käämit kärähtävät, proput palavat. Virossa on lisäksi joukko ilmaisuja, joissa käytetään коKIJANA mielikuvaa (koti)eläimestä (ks. edellisen luvun eläinten ruumiinosiin liittyvät metonyymiset ilmaukset).

Kokijan käsitteistys ASTIANA esiintyy virossa usein yhdessä viHA ON NESTE -mielikuvan kanssa: esimerkiksi viha kandma/pidama 'olla jatkuvasti vihainen' ("kantaa/pitää vihaa"), (oma) viha (kellegi peale) välja valama 'käyttäytyä aggressiivisesti' ("kaataa vihansa jonkun päälle").

Nesteen metaforaa laajentaa mielikuva käymisprosessista ja sen tuloksista (Õim 1999) esimerkiksi viron ilmauksissa pulbitseb/vahutab vihast 'on vaikeaa kontrolloida vihaa' ("pulppuaa/vaahtoaa vihaa"), viha käärib/kobrutab (kellegi) sisemuses 'joku on sisimmässään (jatkuvasti) vihainen' ("viha käy/kuohuu jonkun sisällä"), viha lahtub 'viha katoaa' ("viha väljähtyy"). Näiden esimerkkien perusteella voi muotoilla vielä spesifisemmän metaforan VIHA ON OLUTTA.

Viha käsitteistyy entistä tarkemmin nesteen - sapen - kautta. Tästä kertovat ilmaukset kuten sappi kallama/välja valama 'puhua vihaisesti' 
("kaataa sappea (ulos)"), süda sappi täis 'täynnä tukahdutettua vihaa' ("sydän täynnä sappea"). Suomessakin sappi kiehuu/kiehahtaa/kuohuu. Lisäksi sappea itseään voidaan kuvata ASTIANA: sappi on täysi. Sappiilmausten metonyymistä motivaatiota sekä sen kulttuuriteoreettisia perusteita käsittelimme edellisessä alaluvussa. Viron aineistossa sappi esiintyy rinnakkain katkeruuden ja myrkyn kanssa, esimerkiksi ta hinge täidab kibedus 'hänen henkensä on täynnä katkeruutta', valab kogu oma kibeduse välja 'kaataa ulos kaiken katkeruutensa' (Vainik 2018). Kuten käännökset osoittavat, tällainen käsitteistys toimii samalla tavalla suomessakin.

Molemmista kielistä löytyy myös metafora TUNTEen INTENSIIVIsYys on KUUMUUTTA (Kövecses 2000: 42). Suomen kielessä sanotaan esimerkiksi, että hän käy kuumana, virossa ennast üles kütma 'tulla todella vihaiseksi' ("kuumentaa itsensä"), vihast särtsuma 'puhua vihaisesti' ("sähähtää vihasta"). Kuumuus-metaforan piiriin kuuluu käsitteistys VIHA ON TULTA, joka on edustettuna molemmissa kielissä. Suomessa palamisen metaforaan yhdistyy useita esimerkkejä: pinna palaa, joku polttaa hihansa, hän poltti päreensä, käämit kärähtävät, proput palavat. Virosta löytyy kaunokirjalliseen tyyliin taipuvia ilmauksia kuten viha süttib 'viha syttyy', vihaleek 'vihan liekki', vihapalang 'vihan hehku'. Tulen mukana seuraa savu: savu nousee päästä; virossa sanotaan vihaving 'jatkuva hillitty viha' ("vihan häkä"), vihapahvak 'vihan äkillinen ilmaisu' ("vihantuprahdus").

Voimakasta vihan kokemusta ja sen osoittamista kuvaavat ilmaisut paljastavat joskus, että käsitteistystä ohjaa metafora VIHA ON LUONNONvormA. Tällaisia ovat esimerkiksi seuraavat idiomit: läks marru 'raivostui' ("meni myrskyyn"), möllab vihas 'riehuu vihassa', pikset tegema 'raivota' ("tehdä ukkosta"), pikne lööb sisse 'riita leimahtaa' ("salama iskee"), marus olema 'raivota' ("olla myrskyssä").

Taulukko 2 esittää yhteenvedon metaforiseen siirtoon perustuvista idiomeista. Molemmista kielistä löytyy ilmauksia, jotka perustuvat

\footnotetext{
$6 \quad$ Nämä ilmaukset eivät täytä kaikkia idiomin kriteereitä, vaikka kytkeytyvätkin käsitemetaforaan VIHA ON TULTA.
} 
kansainvälisesti tunnettuihin metaforiin VIHA ON KUUMA NESTE ja VIHA ON PAINEEN ALLA OLEVAA AINETTA ASTIASSA Sekä TUNTEEN INTENSIIVISYYS ON KUUMUUTTA ja VIHA ON TULTA. Erikoista viron käsitteistysmalleissa on vihan esittäminen LUONNONVOIMANA sekä NESTEEN metaforaan perustuvien ilmausten runsaus, samalla kuin tietyt ilmaukset implikoivat, että viha esitetään käyvänä ja vaahtoavana olutta muistuttavana nesteenä. Suomelle omaleimaisia ovat ilmaukset, jotka paljastavat metaforan KOKIJA ON KONE; virossa joissakin tapauksissa KOKIJA ON ELÄIN. Astia ja siihen painetta kohdistava tai sitä täyttävän nesteen ja luonnonvoiman metaforat nostavat erityisesti esiin sen vihakokemuksen aspektin, millä tavalla kokija tulee (tai ei tule) toimeen vihaan liittyvän kasvavan intensiivisyyden kanssa. Vaikuttaa siltä, että viron puhujille tämä näkökulma on olennainen.

TAULUKKо 2. Vihan metaforisen käsitteistyksen lähdealueita virossa ja suomessa

\begin{tabular}{|l|l|l|l|}
\hline Viha & Kokija & Suomi & Viro \\
\hline \multicolumn{2}{|l|}{ VIHA ON KUUMA NESTE ASTIASSA } & + & + \\
\hline \multicolumn{2}{|l|}{ VIHA ON PAINEEN ALLA OLEVAA AINETTA ASTIASSA } & + & + \\
\hline \multicolumn{2}{|l|}{ TUNTEEN INTENSIIVISYYS ON KUUMUUTTA } & + & + \\
\hline TULI & & + & + \\
\hline NESTE & & & + \\
\hline OLUT & & & + \\
\hline MYRKKY & & & + \\
\hline SAPPI & & & + \\
\hline LUONNONVOIMA & & & + \\
\hline & ASTIA & + & + \\
\hline & KONE & + & \\
\hline & ELÄIN & & + \\
\hline
\end{tabular}




\subsection{Vihaskenaarion vaiheet}

Seuraavassa tarkastelemme, miten suomen ja viron suuttumukseen kytkeytyvät idiomit ovat kuvattavissa Lakoffin ja Kövecsesin (1987) viisivaiheisen mallin avulla. Tämän ns. vihan kansanmallin laajempaan taustaan liittyvät tunteiden vaiheittainen luonne (tunteet syntyvät, huipentuvat ja ehtyvät) sekä kuvitelma voimainmittelystä, joka kirjallisuudessa tunnetaan voimadynamiikan nimellä (Talmy 1988: 53). Tunteiden voimadynamiikan perusmielikuvan kannalta oleellisia ovat pyrkijä $(\text { Agonist })^{7}$, tässä tapauksessa kokija, ja häneen kohdistuva vastustaja (Antagonist), emootio (Kövecses 2000: 62-64). Sijoitamme seuraavassa analyysissa suomen ja viron idiomit parhaan kielitietomme mukaan vihan ilmenemisen vaiheisiin sekä tarkastelemme näiden kahden kielen samankaltaisuuksia ja erilaisuuksia.

Ensimmäisessä vihan vaiheessa joku esimerkiksi solvaa tai herjaa asianomaista loukaten tämän tunteita ja synnyttäen vihamielisyyttä. Molemmissa kielissä tästä vaiheesta käytetään metonymiaa HERMOT EDUSTAVAT NEGATIIVISTA MIELIALAA. Erilaisia näkökulmia edustavat ilmaukset läheb närvi ja närvi ajama, suomessa vastaavasti ottaa hermoon ja käydä hermoille. Virolaisilla läheb närv mustaks, suomalaisten mieli mustenee. Molemmissa kielissä MUSTA VÄRI EDUSTAA NEGATIIVIsuUtTA. Suomessa ensimmäisen vihan vaiheen metonyymisiä malleja edustavat myös aivoihin ja päähän viittaavat ilmaukset: ottaa päähän, ottaa kupoliin, ottaa aivoon tai aivosta. Vihan syntymistä intensiivisenä heti alusta lähtien voidaan ilmaista TULEN metaforan viha süttib tai seuraavan metonymian avulla: vetää herneet/porot/rypsit nenään.

Toisessa vaiheessa vihan olemassaoloon sisältyy fysiologisia prosesseja, ja asianomainen kokee ahdistusta ja levottomuutta. Molemmissa kielissä tämän vaiheen kuvauksissa käytetään metaforaa viHA ON KUUMA NESTE ASTIASSA (vrt. viron veri keeb 'veri kiehuu' ja süda keeb vihast 'sydän kiehuu vihasta'; suomen veri kiehuu). Kiehumismielikuvaan

\footnotetext{
Talmyn termit Agonist ja Antagonist on suomennettu pyrkijäksi ja vastustajaksi (ks. Leino 2003: 126).
} 
kietoutuu metonymia SAPEN KITKERYYS EDUSTAA VIHAN EPÄMIELLYтTÄVYYтTÄ: viron sapp hakkab keema 'sappi alkaa kiehua', süda on täis sappi 'sydän on täynnä sappea'; suomen sappi on täysi, se kiehuul kiehahtaa/kuohuu tai jotakuta sapettaa. Vihan voimakkuutta korostavat tässä vaiheessa KUUMUUDEN ja TULEN metaforat: olla/käydä kuumana, Villeltä nousee savu päästä, pinna palaa. Ilmauksissa käämit kärähtävät, proput palavat on lisäyksenä metafora кокIJA ON KONE. Viron ilmaukset keskittyvät paljolti kokijan hahmottamiseen Astiana (jota ilmentävät sydän tai henki). Runsaasti on ns. täynnä olemisen ilmauksia: süda/ hing on täis; südant/hinge täis ajama; hing kargab/saab täis; süda kasvab. ASTIA-metaforaan sopii virossa vihan esittäminen NESTEENÄ - usein jopa käyvänä ja vaahtoavana nesteenä, joka aiheuttaa kokijalle sisäistä painetta.

Kolmannessa vaiheessa kokija voi yrittää kontrolloida vihaansa. Tätä tavoitetta luonnehtii molemmissa kielissä metonymia HERMOT EDUSTAVAT KONTROLLIKYKYä. Virossa pyrkimystä vihan hallitsemiseen ilmentää esimerkiksi sanonta närvid on pingul, ja suomeksi sanotaan, että hermo/pinna on kireällä. Hallitusta vihasta kertovat myös ilmaukset, jotka kuvaavat vihan verbaalisen ilmaisemisen hillintää: viron hambad ristis ja hambaid kiristama; suomen kiristellä hampaita. Metonymia on tässä tapauksessa ELE EDUSTAA viHAA.

Neljännessä vaiheessa kokija menettää tunteidensa hallinnan, aggressiivisuuden määrä kasvaa ja esiintyy vihaisuuteen liittyvää tyypillistä käyttäytymistä. Ärsykkeestä vihareaktion takana saattaa tulla vihan kohde. Vihan aiheuttaja ja vihan kohde ovat vaarassa. Taas on käytössä metonymia HERMOT EDUSTAVAT KONTROLLIKY KYÄ, tällä kertaa kontrollin menetyksen ilmausten kautta: virossa närv ütleb üles 'hermot pettävät' ja suomessa hermo katkeaa, hermot pettävät, nyt meni hermot. Tätä tilannetta voi kuvailla ulkoisen havainnoijan näkökulmasta, visuaalisia "merkkejä" välittävillä metonyymeillä, kuten SILMäT EDUSTAVAT VIHAISTA KATSETTA. Virossa tällaisia ovat silmad välguvad, silmad pilluvad tuld/välke; suomessa käytetään ilmauksia silmät palavat/säkenöi$v a ̈ t / s a l a m o i v a t$. Metonymia TYYPILLINEN ELE EDUSTAA VIHAA motivoi 
ilmauksia käsi on rusikas, rusikat näitama; suomessa vastaavasti nyrkit ojossal tanassa, heristää nyrkkiä.

Molemmissa kielissä löytyy ilmaisuja rationaalisen ajattelun katoamisesta: veri lööb pähe ja veri nousee päähän. Ulkoisen havainnoijan näkökulmasta tätä tilannetta konstruoidaan metonymialla PUNAINEN KASVONVÄRI EDUSTAA VIHAA. Virossa tämä näkyy ilmauksissa hari on punane tai punetab; kasvojen värin vaihtuminen vahvistaa mielikuvaa: vihast sinine/roheline. Suomessa tunteiden hallinnan menetystä voi kuvata karrikoivasti: joku saa näppylöitä. Visuaalisen mielikuvan esittävät myös karvat tai hiukset nousevat pystyyn sekä turri tõmbuma. Tällöin ilmaukset perustuvat metonymiaan VERTIKAALINEN RUUMIINOSA EDUSTAA Negativista emotionaALIsta aKTivointia. Virossa esiintyy lisäksi hyperbolisia ja kokijaa eläimeen samaistavia kuvauksia: okkad/kärss püsti sekä sarvi püsti ajama. Suomen kielessä huomioidaan ja kuvataan vihan aikaansaamaa hengityksen vaikeutumista: vetää herneet/porot/rypsit nenään. Tässä tapauksessa yhdistyvät kaksi metonymiaa: HENGITYKSEN ESTYMINEN EDUSTAA VIHAA ja NENÄ EDUSTAA HENGITYSTÄ.

Neljättä vihan vaihetta voi myös kuvailla ikään kuin itsen jakautumisena kahdeksi minäksi (double self, ks. Lakoff 1996). Tätä kuvitteellista tilannetta heijastavat esimerkiksi ilmaukset revetä nahoistaan ja viroksi endast välja minna 'tulla hyvin vihaiseksi' ("mennä ulos itsestänsä").

Viidennessä vaiheessa asianomainen ikään kuin kostaa kärsimänsä loukkauksen ja näin tilanne palaa tasapainoon. Viha lakkaa. Tämä vihaskenaarion vaihe nousee suomen ja viron vihanilmauksissa esiin kokijan sisäistä tunnereaktiota tai olotilaa kuvaavien, muttei (suoraan) vihan aiheuttajaan suunnattua kostoa kuvailevien ilmausten kautta. Metaforat KOKIJA ON ASTIA sekä VIHA ON NESTE motivoivat viron ulosmenoa ja uloskaatamista ilmaisevia idiomeja kuten viha välja valama ja sappi kallama 'puhua vihaisesti' ("kaataa sappea"). Metafora viHA ON KUUMA NESTE ASTIASSA yhdessä metonyymisen mallin SAPEN KITKERYYS EDUSTAA VIHAN EPÄMIELLYTTÄVYYTTÄ motivoivat ilmausta sapp keeb üle. Joidenkin ilmausten taustalla on metafora VIHA ON PAINEEN ALLA OLEVAA AINETTA ASTIASSA, joka tässä vihaskenaarion vaiheessa 
perustuu kuvitelmaan räjähtämisestä. Suomen kielessä tällaisia ilmauksia ovat esimerkiksi (joku) räjähtää, hän oli haljeta kiukkuunsa, minä repesin / minulla repesi, revetä nahoistaan; virossa vastaavasti ta plahvatas vihast 'hän ei pystynyt hallitsemaan vihaansa' ("hän räjähti vihasta") ja vihast lóhki minema 'olla äärimmäisen suutuksissa' ("haljeta vihasta").

Virossa kokijaa ei hahmoteta tilanteen vastuulliseksi osallistujaksi, kun käytetään metaforaa VIHA ON LUONNONVOIMA (marus olema, tormitsema, pikne lööb sisse). Suomessa hyödynnetään kielikuvia, joissa kokija toimii itse aktiivisena osanottajana, vaikkakaan ei ihan järkevästi, jopa autoaggressiivisesti: repii pelihousunsa/paitansa/rotsinsa/hameensa).

Yhteenvetona voi sanoa, että viron ja suomen ilmaukset kuvailevat prototyyppisiä vihaskenaarion vaiheita yleisesti ottaen samankaltaisesti, esimerkiksi siten, että hermoihin viitataan melkein jokaisessa vaiheessa ja kokijan tunteiden kuvauksessa käytetään metaforia viHAN INTENSIIVISYYS ON KUUMUUS, VIHA ON KUUMA NESTE ASTIASSA sekä viHA ON TULI. Käytössä on myös räjähtämisen kielikuvia. Eroja löytyy ASTIA-metaforan kielentämisessä: virossa viha kytketään sydämeen tai henkeen, mutta suomessa päähän (aivoihin). Viron kielessä painottuu kokijan esittäminen astiana, joka sisältää nesteeksi kuvitellun vihan; viidennessä vaiheessa vihan voi "kaataa ulos". Suomessa vihan kokija voidaan esittää koneena, virossa taas eläimenä. Virossa intensiivistä vihaa vertaillaan luonnonvoimaan, jolloin kokija tavallaan vapautetaan vastuusta. Suomessa sitä kuvaillaan hyperbolisesti kokijan autoaggressiivisena käyttäytymisenä.

\section{Lopuksi}

Suuttumusta kuvaaville idiomeille on usein tyypillistä, että yhdestä ja samasta fraasista on olemassa lukuisia variantteja: esimerkiksi suomen ottaa päähän/kupoliin/kaaliin ja viron süda/hing sai täis, süda/hing sai/ kargas täis jne. Toisintojen määrä on merkki siitä, että kummassakaan kielessä ei ole kyse yksittäisistä kuvaannollisista kielennyksistä vaan käsitteellisistä (mm. metaforisista ja metonyymisistä) ilmauksista. 
Virolaisilla tai suomalaisilla idiomeilla on yhteisiä aihepiirejä. Ihmisen tunteet eivät ole irrotettavissa fyysisistä toiminnoista. Esimerkiksi sappirakkoon varastoidulla sappinesteellä on tärkeä osa ruuansulatuksessa. Sen erittymisen häiriöt saattavat aiheuttaa kipuja, ja ruumiillinen pahoinvointi vertautuu ärtymyksen aiheuttamaan mielipahaan. Sydämen ja hermoston toiminnallisten häiriöiden puolestaan tiedetään johtuvan osittain stressistä, joka voi olla seurausta voimakkaasta vihastumisesta. Toisaalta vaikkapa nyrkkiin puristuvien käsien ja silmien avulla suuttumus on viestittävissä myös puhekumppanille.

Kieli heijastaa myös kulttuuriteorioiden vaikutusta käsitteistämiseen. Vaikkapa sapen kiehumiseen viittaavat ilmaukset saattavat hyvinkin olla lähtöisin antiikin läk̈ketieteestä tunnetusta ns. ruumiinnesteiden teoriasta (ks. luku 4.1).

Kielessä on ilmaisuja, jotka antavat hieman tarkemman käsityksen siitä, millaiseksi aineeksi, olioksi tai ilmiöksi viha kuvitellaan. Myös tunteen syklinen luonne, sen intensiteetin kasvun ja laskun vaiheet tai huipentuma ovat nähtävissä idiomeissa. Jotkin metaforat paikantavat tunteet ikään kuin ihmisen sisään, jolloin viitataan elinten, kuten sydämen ja veren, muutoksiin. Idiomiin voivat kirjautua myös kehossa havaittavat muutokset. Joskus fraasi tuo esiin tunteen hallitsemattomuuden tai viha vertautuu (fyysiseen) tuskaan tai huonoon oloon. Joissain näistä näkökohdista, esimerkiksi intensiteetin ja syklisyyden yhteydessä, olennaista on itse tunteen olemuksen kuvaaminen, toisissa puolestaan kokijan näkökulma, hänen fyysiset oireensa tai kärsimyksensä. Mikäli metaforassa korostuu jompikumpi aspekti, sitä voidaan kutsua kuvan kokemukselliseksi keskipisteeksi (Kövecses 2006). Tunnetta voidaan kuvailla myös ulkoisen havainnoijan näkökulmasta, mikä korostaa tilanteen visuaalisuutta (Vainik 2011: 53). Viron kielestä on todettu, että liioittelevien ja absurdien kuvausten avulla emotionaalisen reaktion voimakkuus voidaan tehdä naurunalaiseksi (Vainik 2017: 20).

Kuvallisuuden lähdealueet ovat monesti sukukielissä samoja, vaikka lekseemit vaihtelevatkin. Tuli ja palaminen ovat hallitsemattomuudessaan luontevia vertailun lähtökohtia. Myös vihastumisen vaiheet ja 
intensiivisyyden erot ovat nähtävissä sekä virolaisissa että suomalaisissa idiomeissa: vihan vaiheita seurattaessa huomioidaan vihan synty, sen vaikutus kokijaan, pyrkimys vihan kontrollointiin, vihan voimakkuuden nousu sekä vihaan kokijalle aiheuttaman paineen katoaminen.

Johdannossa totesimme, että verrattaessa aikaisemmin viron ja suomen viha-sanan kirjaimellisia merkityksiä on löydetty lähinnä yhtäläisyyksiä mutta myös joitain eroja. Virolaiset voivat yrittää selviytyä vihasta pysymällä passiivisina. Suomalaiset puolestaan kokevat jonkin verran enemmän tarvetta toimia tai ainakin liikkua; he haluavat ilmaista voimakkaan tunteensa ja olla näkyvämpiä kuin virolaiset. He eivät myöskään sulje pois hajotettavissa olevien esineiden hajottamista (Realo ym. 2013: 334).

Vihaan liittyvien idiomien tarkastelu tässä tutkimuksessa vahvistaa jossain määrin aikaisempia tuloksia. Viron idiomit kuvaavat vihaa kokijan sisäisenä ilmiönä (kokijan käsitteistäminen ASTIANA), jolloin viitataan sisäelimiin, kuten keuhkot, maksa ja rakko, sekä naurunalaistetaan vihan ulkoisia ilmentymiä vertaamalla ihmistä eläimiin. Suomen kielessä suositaan erityisesti ilmauksia, jotka kuvaavat vihan vaikutusta aivojen toimintaan (negatiivinen aktivointi) sekä autoaggressiivisuuteen ja vaatteiden rikkomiseen suuntautuva käyttäytymistä (räjäyttää hattunsa; repiä pelihousunsa/paitansalrotsinsa tai polttaa hihansal hameensa). Vihan syntymistä suomessa kuvaa voimakas kielikuva vetää herneet/porot/rypsit nenään.

Tutkimustuloksemme tukevat aiempaa havaintoa, jonka mukaan kulttuurit saattavat erota keskenään vaikkapa siinä, miten vihan emootiota käsitellään ja miten siihen suhtaudutaan. Onko esimerkiksi vihan ilmaiseminen ja jopa sen toteuttaminen luvallista, vai edellyttävätkö yhteiskunnan normit vihan pitämistä piilossa (Realo ym. 2013: 328)? Vaikka Viro ja Suomi ovat kulttuurisesti hyvin läheisiä, pystyimme havaitsemaan joitakin tendenssejä, jotka viittaavat erilaiseen vihan käsitteistämiseen: virossa ajatustapaa ohjaa vihan kantaminen kokijaASTIASSA, mutta suomen kielikuvissa löytyy enemmän vihaista toimintaa ja käyttäytymistä. 
Vihan käsitteistys monivaiheisena tapahtumaketjuna (vihan synty, sen vaikutus kokijaan, pyrkimys kontrolloida vihaa, kontrollin menetys, vihan aiheuttama käyttäytyminen) on yhteydessä sellaisiin inhimillisiin kokemuksiin, joista perimmältään kuvaannollisten ilmausten tarve on lähtöisin. Käsiteltyjä vihametonymioita ja -metaforia ei käytetä huvin vuoksi vaan siksi, että tiettyjä psykologisia ilmiöitä on vaikeaa ellei mahdotonta ilmaista sanojen suorien merkitysten kautta. Toisaalta käsitteistyksessä on huomioitava, että käsitteistäjän arvio tilanteesta suhteessa normiin saattaa ilmetä myös liioitteluna tai huumorina.

\section{Kiitokset}

Kiitämme Asta Õimia ja Hannu Remestä muun muassa avusta aineiston hankinnassa sekä nimettömiä arvioijia osuvista kommenteista. Tutkimusta on tukenut Viron tiedeagentuurin projekti PSG227 "Eesti keele sõnaliikide kategooriad korpusanalüüsi valguses”.

\section{Lähteet}

Bednarek, Monika 2008. Emotion Talk across Corpora. Houndmills \& New York: Palgrave Macmillan. https://doi.org/10.1057/9780230285712

Bokor, Zsuzsanna 1997. Body-based constructionism in the conceptualization of anger. - Paper 17 in the C.L.E.A.R. series (Cognitive Linguistics: Explorations, Applications, Research). Working papers of the Department of English, Hamburg University, and Department of American Studies. Budapest: Eötvös Lorand University.

Chon, Kyum Koo 2002. Cultural aspects of anger. - Claes von Hofsten, Lars Bäckman (eds.). Psychology at the Turn of the Millennium. Vol. 2: Social, Developmental, and Clinical Perspectives. East Sussex, UK: Psychology Press, 323-346.

Dobrovol'skij, Dmitrij, Elisabeth Piirainen 2005. Figurative Language: Cross-Cultural and Cross-Linguistic Perspectives. Current Research in the Semantics/Pragmatics Interface 13. Amsterdam: Elsevier.

Gehweiler, Elke, Iiris Höser, Undine Kramer 2007. Types of changes in idioms: Some suprising results of corpus research. - Christiane Fellbaum (ed.). Idioms and Collocations: Corpus-based Linguistic and Lexicographic Studies. London \& New York: Continuum, 109-137. 
Gibbs, Raymond 1993. Why idioms are not dead metaphors? - Cristina Cacciari, Patrizia Tabossi (eds.). Idioms: Processing, Stucture and Interpretation. Hillsdale: Lawrence Erlbaum Associates, 57-77.

Goossens, Louis 1990. Metaphtonymy: The interaction of metaphor and metonymy in expressions for linguistic action. - Cognitive Linguistics 1 (3), 323-340. https://doi.org/10.1515/cogl.1990.1.3.323

Erelt, Mati 2017. Sissejuhatus süntaksisse ['Introduction to syntax']. - Mati Erelt, Helle Metslang (toim.). Eesti keele süntaks. Eesti keele varamu III. Tartu: Tartu Ülikooli Kirjastus, 537-564.

Flores d'Arcais, Giovanni B. 1993. The comprehension and semantic interpretation of idioms. - Cristina Cacciari, Patrizia Tabossi (eds.). Idioms: Processing, Stucture and Interpretation. Hillsdale: Lawrence Erlbaum Associates, 79-98.

Geeraerts, Dirk, Stefan Grondelaers 1995. Looking back at anger: Cultural traditions and metaphorical patterns. - John Taylor, Robert MacLaury (eds.). Language and the Cognitive Construal of the World. Berlin \& New York: Mouton de Gruyter, 153-179.

Häkkinen, Kaisa 2000. Idiomin määritelmiä ['Definitions of an idiom']. - Eeva Lähdemäki, Yvonne Bertills (toim.). Fennistica fausta in honorem Mauno Koski septuagenarii. Turku: Åbo Akademi, 1-15.

Hänninen, Harto, Petri Kemppinen 1994. Lähtöruutu sarjakuvaan. Yle.

Kehayov, Petar, Virve Vihman 2014. The lure of lability: A synchronic and diachronic investigation of the labile pattern in Estonian. - Linguistics 52 (4), 1061-1105. https://doi.org/10.1515/ling-2014-0016

Kövecses, Zoltán 2000. Metaphor and Emotion: Language, Culture, and Body in Human Feeling. Cambridge: Cambridge University Press.

Kövecses, Zoltán 2002. Metaphor: A Practical Introduction. Oxford: Oxford University Press.

Kövecses, Zoltán 2006. Embodiment, experiential focus, and diachronic change in metaphor. - Roderick W. McConchie, Olga Timofeeva, Heli Tissari, Tanja Säily (eds.). Selected Proceedings of the 2005 Symposium on New Approaches in English Historical Lexis. Somerville, MA: Cascadilla Proceedings Project, 1-7.

Lakoff, George 1996. Sorry, I'm not myself today: The metaphor system for conceptualizing the self. - Gilles Fauconnier, Eve Sweetser (eds.). Spaces, Worlds, and Grammar. Chicago: University of Chicago Press, 91-123.

Lakoff, George, Mark Johnson 1980. Metaphors We Live By. Chicago: University of Chicago Press. 
Lakoff, George, Zoltán Kövecses 1987. The cognitive model of anger inherent in American English. - Dorothy Holland, Naomi Quinn (eds.). Cultural Models in Language and Thought. Cambridge: Cambridge University Press, 195-221. https://doi.org/10.1017/CBO9780511607660.009

Lakoff, George, Mark Turner 1989. More than Cool Reason: A Field Guide to Poetic Metaphor. Chicago \& London: University of Chicago Press. https:// doi.org/10.7208/chicago/9780226470986.001.0001

Langacker, Ronald W. 1987. Foundations of Cognitive Grammar I: Theoretical Prerequisites. Stanford: Stanford University Press.

Langlotz, Andreas 2006. Idiomatic Creativity: A Cognitive-lingustic Model of Idiom-representation and Idiom-variation in English. Amsterdam \& Philadelphia: John Benjamins. https://doi.org/10.1075/hcp.17

Leech, Geoffrey N. 1974. Semantics: The Study of Meaning. Harmondsworth: Penguin.

Leech, Geoffrey N., Michael H. Short 1986. Style in Fiction: A Linguistic Introduction to English Fictional Prose. Fifth impression. London: Longman.

Leino, Jaakko 2003. Antaa sen muuttua. Suomen kielen permissiivirakenne ja sen kehitys ['The permissive structure of the Finnish language and its development']. Suomalaisen Kirjallisuuden Seuran toimituksia 900. Helsinki: Suomalaisen Kirjallisuuden Seura.

Maalej, Zouheir 2004. Figurative language in anger expressions in Tunisian Arabic: An extended view of embodiment. - Metaphor and Symbol 19 (1), 51-75. https://doi.org/10.1207/S15327868MS1901_3

Matsuki, Keiko1995. Metaphors of anger in Japanese. - John Taylor, Robert MacLaury (eds.). Langauage and the Cognitive Construal of the World. Berlin: Mouton the Gruyter, 137-151.

Mesquita, Batja, Nico H. Frijda, Klaus R. Scherer 1997. Culture and emotion. John W. Berry, Pierre R. Dasen, T. S. Saraswathi (eds.). Handbook of CrossCultural Psychology. Volume 2: Basic Processes and Human Development. Needham Heights, MA: Allyn \& Bacon, 255-297.

Moon, Rosamund 1998. Fixed Expressions and Idioms in English: A Corpusbased Approach. Oxford: Oxford University Press.

Muikku-Werner, Pirkko 2017. Fraase laenamas: eestlaste ja soomlaste tõlkestrateegiaid ['Loan idiom phrases: Estonian and Finnish translation strategies']. - Mäetagused 69, 59-76. https://doi.org/10.7592/MT2017.69. muikku_werner

Muikku-Werner, Pirkko, Jarmo Harri Jantunen, Ossi Kokko 2008. Suurella sydämellä ihan sikana: suomen kielen kuvaileva fraasisanakirja ['Descriptive Dictionary of Finnish Phraseology']. Jyväskylä: Gummerus. 
MITEN KUVAILLA VIHAA?

Murmann, Maximilian 2019. Inchoative Emotion Verbs in Finnish: Argument Structures and Collexemes. Tübingen: Narr Francke Attempto Verlag.

Mäntylä, Katja 2004. Idioms and Language Users: The Effect Characteristics of Idioms on their Recognition and Interpretation by Native and Non-native Speakers of English. Jyväskylä Studies in Humanities 13. Jyväskylä: Jyväskylän yliopisto.

Nenonen, Marja 2002. Idiomit ja leksikko. Lausekeidiomien syntaktisia, semanttisia ja morfologisia piirteitä suomen kielessä ['Idioms and the Lexicon: Syntactic, Semantic and Morphological Features of Finnish Phrasal Idioms']. Joensuun yliopiston humanistisia julkaisuja 29. Joensuu: Joensuun yliopisto.

Nummenmaa, Lauri 2010. Tunteiden psykologia ['The Psychology of Emotions']. Helsinki: Tammi.

Nuutinen, Liisa 2012. Ottaako hermosta, ottaako päähän? - Kielikello 3, 31.

Nunberg, Geoffrey, Ivan A. Sag, Thomas Wasow 1994. Idioms. - Language 70 (3), 491-538. https://doi.org/10.1353/lan.1994.0007

Onikki-Rantajääskö, Tiina 2001. Sarjoja: Nykysuomen paikallissijaiset olotilanilmaukset kielen analogisuuden ilmentäjinä ['Patterns and Analogy: A Case Study of State-denoting Local Case Constructions in Modern Finnish']. Helsinki: Suomalaisen Kirjallisuuden Seura.

Onikki-Rantajääskö, Tiina 2006. Metonymy in locatives of state. - Marja-Liisa Helasvuo, Lyle Campbell (eds.). Grammar from the Human Perspective: Case, Space and Person in Finnish. Current Issues in Linguistic Theory 277. Amsterdam: John Benjamins, 67-100. https://doi.org/10.1075/ cilt.277.08oni

Realo, Anu, Mari Siiroinen, Heli Tissari, Liisi Kööts-Ausmees 2013. Finno-Ugric emotions: The meaning of anger in Estonian and Finnish. - Johnny J. R. Fontaine, Klaus Scherer, Cristina Soriano (eds.). Components of Emotional Meaning: A Sourcebook. Oxford: Oxford University Press, 328-338. https://doi.org/10.1093/acprof:oso/9780199592746.003.0022

Taylor, John R., Mbense Thandi G. 1998. Red dogs and rotten mealies: How Zulus talk about anger. - Angeliki Athanasidou, Elzbieta Tabakowska (eds.). Speaking of Emotion: Conceptualization and Expression. Berlin: Mouton the Gruyter, 191-226.

Talmy, Leonard 1988. Force dynamics in language and cognition. - Cognitive Science 12 (1), 49-100. https://doi.org/10.1207/s15516709cog1201_2

Tuovila, Seija 2005. Kun on tunteet: Suomen kielen tunnesanojen semantiikkaa ['Because We have Emotions: On the Semantics of Finnish Words for 
Emotions']. Oulu: University of Oulu, Department of Finnish, Information Studies and Logopedics. http://herkules.oulu.fi/isbn9514278070

Vainik, Ene 2002. Emotions, emotion terms and emotion concepts in an Estonian folk model. - Trames 6, 322-341.

Vainik, Ene 2011. The dynamic body parts in the Estonian figurative descriptions of emotions. - Zouheir A. Maalej, Ning Yu (eds.). Embodiment via Body Parts: Studies from Various Languages and Cultures. Human Cognitive Processing 31. Amsterdam \& Philadelphia: John Benjamins, 41-70. https://doi.org/10.1075/hcp.31.06vai

Vainik, Ene 2014. Early emotional contacts with the Indo-Europeans: Lexical evidence of Estonian against a broader background. - ESUKA/JEFUL 5-2, 139-167. https://doi.org/10.12697/jeful.2014.5.2.07

Vainik, Ene 2016. Eesti tunded. Sõnaportreed ['Estonians' Feelings. The words portraited']. Tallinn: Eesti Keele Sihtasutus.

Vainik, Ene 2017. Tunnetest, piltlikult ['About emotions, figuratively']. - Mäetagused 69, 9-38. https://doi.org/10.7592/MT2017.69.vainik

Vainik, Ene 2018. Emotion meets taste: Taste-motivated emotion terms in Estonian. - Folklore: Electronic Journal of Folklore 71 (1), 129-155. https:// doi.org/10.7592/FEJF2018.71.vainik

Vainik, Ene, Anneli Velt 2006. Viha metafoorid ja kognitiivne mudel eesti keeles ['Metaphors of anger and its cognitive model in Estonian']. - Keel ja Kirjandus 2, 104-121.

VISK = Hakulinen, Auli, Maria Vilkuna, Riitta Korhonen, Vesa Koivisto, Tarja Riitta Heinonen, Irja Alho 2004. Iso suomen kielioppi ['Comprehensive Grammar of Finnish']. Helsinki: Suomalaisen Kirjallisuuden Seura. http:// scripta.kotus.fi/visk

Wierzbicka, Anna 1999. Emotions across Languages and Cultures: Diversity and Universals. Cambridge: Cambridge University Press. https://doi. org/10.1017/CBO9780511521256

Õim, Asta 2003. Armastus ja õnn eestlaste maailmapildis ['Love and happiness in an Estonian's view']. - Keel ja Kirjandus 11, 802-813.

Õim, Asta 2017. Fraseoloogiasõnaraamat ['The Dictionary of Estonian Phraseology']. Tallinn: Eesti Keele Sihtasutus.

Õim, Asta (toim.) 2020. Eesti kõnekäänud I-II ['Estonian proverbs']. Monumenta Estoniae antiquae VII. Tartu: EKM Teaduskirjastus.

Õim, Asta, Katre Õim 2019. Lähtekohti eesti fraseoloogia käsitlemiseks ['Theoretical basis of the Estonian Phraseology']. Tallinn: Eesti Keele Sihtasutus.

Õim, Haldur 1997. Eesti keele mentaalse maailmapildi allikaid ja piirjooni ['The sources and principles of the mental worldview in the Estonian 
MITEN KUVAILLA VIHAA?

language']. - Mati Erelt, Meeli Sedrik, Ellen Uuspõld (toim.). Pühendusteos Huno Rätsepale: 28. 12. 1997. Tartu Ülikooli eesti keele õppetooli toimetised 7. Tartu: Tartu Ülikool, 255-268.

Õim, Haldur 2008. Kognitiivne pööre ['The cognitive turn']. - Keel ja Kirjandus 8-9, 617-627.

Yu, Ning1995. Metaphorical expressions of anger and happiness in English and Chinese. - Metaphor and Symbolic Activity 10 (2), 59-92. https://doi. org/10.1207/s15327868ms1002_1 


\title{
How to describe anger? A comparison of Estonian and Finnish idioms from the perspective of cognitive linguistics
}

\author{
ENE VAINIK ${ }^{1}$, \\ PIRKKO MUIKKU-WERNER 2 , \\ GEDA PAULSEN 1,3 \\ Institute of the Estonian Language ${ }^{1}$, University of Eastern Finland ${ }^{2}$, \\ Uppsala University ${ }^{3}$
}

This study focuses on a comparison of two sister languages, Estonian and Finnish. The purpose is to compare the idiomatic expressions which describe the emotion of anger in order to find out the similarities and differences in its conceptualisation and lexicalisation. The findings are interpreted by using the framework of cognitive metaphor theory.

The idioms of both languages fit onto the five-stage scenario like folk model of anger (the offense and beginning of anger; the (physiological) effects of anger on Self; the attempt to control the emotion; losing the control; retribution i.e. aggressive behaviour). The cognitive model represents these aspects of the anger event which are conceptualised by using figurative expressions.

Both languages provide a rich array of expressions motivated by cognitive metonymies. The emotion is described by referring to its bodily symptoms, i.e. the expected changes in the position or function of one's body parts (both internal and external). The descriptions vary from realistic (e.g., rusikat näitama (Est) 'to demonstrate aggressivity', lit. 'to show one's fist') to unrealistic and even absurd ones (e.g., vetää herneet nenään (Fin) 'to become angry', lit. 'to aspirate peas into one's nose'). The differences lie in particular elements of the (human) body or physiological processes these languages focus on: Finnish idioms refer also to the (negative) activation of the brain and to a pattern of autoaggressive behaviour while the Estonian idioms pay more attention to the feeling of pressure in one's chest and - on the other hand - also refers to the body parts of (domestic) animals. The latter expressions mix the metonymies 
with metaphoric mapping MAN IS AN ANIMAL and subject the (intensity of) emotional reaction to ridicule.

In regard to the cognitive metaphors, some widespread ones could be detected in both of the languages, namely ANGER IS HOT FLUID IN A CONTAINER, THE INTENSITY OF ANGER IS HEAT and ANGER IS FIRE. Estonian tends to exploit the metaphor ANGER IS FLUID IN A CONTAINER more widely, by specifying the nature of fluids (such as poison and beer/alcohol) and the nature of containers such as one's heart and spirit. In Estonian also the metaphor ANGER IS A NATURAL FORCE is used in order to conceptualise one's inability to control the emotion. The reifying metaphor EXPERIENCER IS A MACHINE seems to be a Finnish peculiarity.

The results were found to reinforce the results of a previous study into the literal concepts of anger by Estonians and Finns in which the concepts were found to be very similar with only minor differences in respect of the action tendencies. The Estonians interviewed in the previous study stated that they would prefer staying passive while angry. Similarly, the Estonian idioms in the present study reflect the aspects of containing the emotion and its effects on the experiencing Self. The Finns, in contrast, believed that they would prefer being active or moving, and the Finnish idioms reflect some interesting patterns of autoaggressive behaviour (e.g. polttaa hihansa, lit. 'to burn one's sleeves' or repiä pelihousunsa, lit. 'to shred one's game shorts'.

Keywords: anger; idioms; cognitive metaphor theory; metonymy; metaphor; scenario

\section{Ene Vainik}

Roosikrantsi 6, 10119 Tallinn, Estonia

Ene.Vainik@eki.ee

Pirkko Muikku-Werner

Itä-Suomen yliopisto PL 111, 80101 Joensuu, Finland

pirkko.muikku-werner@uef.fi

Geda Paulsen

Roosikrantsi 6, 10119 Tallinn, Estonia

Geda.Paulsen@eki.ee

Geda.Paulsen@moderna.uu.se 